\title{
Genomic and Haplotype Comparison of Butanol Producing Bacteria Based on 16S rDNA
}

Ekwan Nofa Wiratno $^{1^{*}}$, Suharjono ${ }^{1}$, Agustin Krisna Wardani ${ }^{2}$

\author{
${ }^{1}$ Department of Biology, Faculty of Mathematics and Natural Sciences, Brawijaya University, Malang, Indonesia \\ ${ }^{2}$ Department of Agricultural Product Technology, Faculty of Agriculture Technology, Brawijaya University, Malang, Indonesia
}

\section{ABSTRACT}

High butanol demand for transportation fuel triggers butanol production development. Exploration of butanolproducing bacteria using genomic comparison and biogeography will help to develop butanol industry. The objectives of this research were butanol production, genome comparison and haplotype analysis of butanolproducing bacteria from Ranu Pani Lake sediment using $16 \mathrm{~S}$ rDNA sequences. The highest butanol concentrations were showed by Paenibacillus polymyxa RP 2.2 isolate (10.34 g.L $\mathrm{L}^{-1}$ ), followed by Bacillus methylotrophicus RP 3.2 and B. methylotrophicus RP 7.2 isolate (10.11 g. $\mathrm{L}^{-1}$ and 9.63 g.L $\mathrm{L}^{-1}$ ) respectively. Paenibacillus polymyxa RP 2.2 showed similarity in nucleotide composition (ATGC) with B. methylotrophicus RP 3.2, B. methylotrophicus RP 7.2, P. polymyxa CR1, Bacillus amyloliquefaciens NELB-12, and Paenibacillus polymyxa WR-2. Clostridium acetobutylicum ATCC 824 showed similarity in nucleotide composition (ATGC) with Clostridium saccharoperbutylacetonicum N1-4, and Clostridium saccharobutylicum Ox29. The lowest G+C content was C. saccharobutylicum Ox29 (51.35\%), and the highest was B. methylotrophicus RP 7.2 (55.33\%). Conserved region of $16 \mathrm{~S}$ rDNA (1044 bp) were consisted of 17 conserved sequences. The number of Parsimony Informative Site (PIS) was 319 spot and single tone was 48 spot. We found in this study that all of butanolproducing bacterial DNA sequences have clustered to 8 haplotypes. Based on the origin of sample, there were three haplotype groups. Bacteria from group A were could produce butanol 8.9-10.34 g.L $\mathrm{L}^{-1}$, group B 9.2-14.2 g. $\mathrm{L}^{-1}$ and group $\mathrm{C}$ was could produce butanol $0.47 \mathrm{~g}$. $\mathrm{L}^{-1}$. The haplotype analysis of bacteria based on $16 \mathrm{~S}$ rDNA sequences in this study could predict capability of butanol production.

Keywords: $16 S$ rDNA, bacteria, butanol, haplotype

\section{INTRODUCTION}

Petroleum limitation gives effect to the development of bio-fuel to fulfill transportation demand. Butanol and ethanol are alternative energy that was highly recommended for transportation. Butanol has higher energy density, lower heating value (LHV), higher hydrophobicity and lower evaporation than ethanol [1]. Butanol can be produced by Clostridium [2], Bacillus, and Paenibacillus [3; 4].

Clostridium acetobutylicum, Clostridium beijerinckii, and Clostridium saccharoperbutylacetonicum, are Clostridia species that could produce butanol [5]. The number of Bacillus and Paenibacillus that could produce butanol, there are Bacillus sp. 15, Bacillus

\footnotetext{
*Corresponding author:

Ekwan Nofa Wiratno

Department of Biology, Faculty of Mathematics and Natural

Sciences, Brawijaya University, Malang, Indonesia

Jl. Veteran, Malang 65145, Indonesia

E-mail: ekwanwiratno@gmail.com
}

amyloliquefaciens NELB-12 [4; 6], and Paenibacillus polymyxa CR1 [3].

Microbial biogeography is essential to predict metabolism and other activity that will give an advantage to human [7]. However, there have not been any analysis on relationship between butanol production and microbial biogeography. The objective of this study is to compare butanol production capability, profile nucleotide composition and analyse haplotype based on $16 \mathrm{~S}$ rDNA sequences.

\section{MATERIALS AND METHODS \\ Collection of the samples}

Samples were collected from 5 locations of Ranu Pani edge, Indonesia. Samples stored in ice boxes. Bacterial reference sequences accessed from Genebank NCBI (http://www.ncbi.nlm.nih.gov/). Information on butanol production capability was obtained from some references (Table 1). 
Tabel 1. PCR composition material

\begin{tabular}{clcc}
\hline No. & \multicolumn{1}{c}{ Solution } & Volume $(\mu L)$ & Concentration \\
\hline 1 & ddH $_{2} \mathrm{O}$ & 6 & \\
2 & PCR mix $\left(\right.$ i-Taq $\left.^{T M}\right)$ & 15 & \\
3 & Primer Forward & 3 & $30 \mathrm{pmol}$ \\
4 & Primer Reverse & 3 & $30 \mathrm{pmol}$ \\
5 & DNA template & 3 & $<1 \mu \mathrm{g}$ \\
& Total & 30 & \\
\hline
\end{tabular}

Table 2. Reaction condition for PCR

\begin{tabular}{clcc}
\hline No. & Reaction & Temperature $\left({ }^{\circ} \mathrm{C}\right)$ & Time (min) \\
\hline 1 & Initial denature & 94 & 4 \\
2 & 35 cycles: & & \\
& Denature & 94 & 1 \\
& Annealing & 55 & 1 \\
& Extension & 72 & 1 \\
3 & Final extension & 72 & 5 \\
\hline
\end{tabular}

\section{Isolation of bacteria}

Twenty five grams of sediment from Ranu Pani Lake was suspended in $225 \mathrm{ml}$ sterile aquadest. Suspension was diluted serially until 10-6 and added $9 \mathrm{ml}$ Tryptone Yeast Extract Acetate (TYA) agar medium (6 $\mathrm{g}$ bacto tryptone (Bacto); 2 g yeast extract (Bacto); $3 \mathrm{ml}$ acetic acid; $0.5 \mathrm{~g} \mathrm{KH}_{2} \mathrm{PO}_{4} ; 0.3 \mathrm{~g} \mathrm{MgSO}_{4} .7 \mathrm{H}_{2} \mathrm{O} ; 0.01 \mathrm{~g}$ $\mathrm{FeSO}_{4} .7 \mathrm{H}_{2} \mathrm{O} ; 20 \mathrm{~g}$ glucose and $20 \mathrm{~g}$ agar (Bacto) per liter, $\mathrm{pH} 6,5$ standardized using $1 \mathrm{~N} \mathrm{NaOH}$ and sterilized at $115^{\circ} \mathrm{C}, 15$ minutes) [8] and incubated at $27^{\circ} \mathrm{C}$ for 48 hours.

\section{Butanol production}

Two and half mililiter of bacterial culture in Thioglicolate medium (was incubated at $30^{\circ} \mathrm{C}, 48$ hours) was transferred to $22.5 \mathrm{~mL}$ modified TYA medium pH 6.5 (without glucose, added 1\% filter paper Whatmann no 1 ) and incubated at $30^{\circ} \mathrm{C}, 7$ days. Butanol was measured at the end of fermentation using Gas Chromatography (GC).

\section{$16 S \mathrm{rDNA}$ isolation and amplification}

DNA was isolated from the highest butanol producing isolates using a modified method of Ausubel et al. [9]. Sequences of $16 \mathrm{~S}$ rDNA were amplified using a couple of primer (27F: 5'-AGAGTTTGATCMTGGCTC-3'; 1492R: 5'-GGTTACCTTGTTACGACTT-3') [10]. Material composition and reaction condition of PCR are shown in Table 1 and Table 2 [11].

\section{$16 S$ rDNA purification and sequencing}

Purification and sequencing of $16 \mathrm{~S}$ rDNA sequence performed in First Base, Malaysia. Sequences were submitted to NCBI (KT036393, KT036394, and KT036395).

\section{$16 S$ rDNA profiling}

16S rDNA was profiled (nucleic acid composition, pattern and conserve sequences) using Bioedit and MEGA 6.06 for Windows.

\section{Haplotype}

Sequences of $16 \mathrm{~S}$ rDNA bacteria were analysis haplotype using DNAsp 5 and Haplotype Network 4.6.1.3 for Windows.

\section{RESULTS AND DISCUSSION \\ Butanol production}

There are 13 isolates of bacteria cultured from Ranu Pani Lake sediment. The highest butanol concentrations were resulted by $P$. polymyxa RP 2.2 isolate (10.34 g. $\mathrm{L}^{-1}$, in 3 days fermentation) and then Bacillus methylotrophicus RP 3.2 and $B$. methylotrophicus RP 7.2 isolate (10.11 g. $\mathrm{L}^{-1}$, in 5 days and 9.63 g. $\mathrm{L}^{-1}$, in 3 days fermentation) using filter paper substrate. On the other hand, Table 4 shows that B. amyloliquefaciens NELB-12 could produce 8.9 g.L $\mathrm{L}^{-1}$ butanol using 30 g.L $\mathrm{L}^{-1}$ starches [4]. Using CMC $C$. Saccharoperbutylacetonicum N1-4 could produce 0.47 g. $\mathrm{L}^{-1}$ butanol [12] whereas $C$. acetobutylicum ATCC 824 and Clostridium saccharobutylicum Ox29 could produce 14.2 g.L - $^{-1}$ (using 80 g.L.$^{-1}$ glucose) and 9.2 g.L ${ }^{1}$ (using 60 g. $\mathrm{L}^{-1}$ glucose) butanol $[13,14]$. There is no information on butanol production capability for Paenibacillus. Some references only refer those potential $[15,16]$.

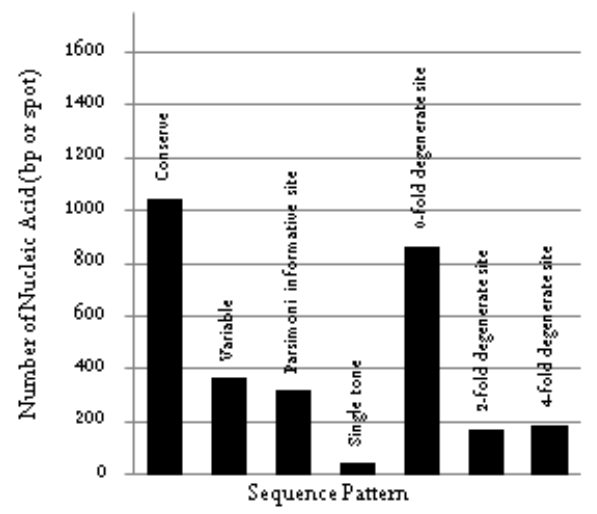

Figure 1. Butanol-producing bacterial 16S rDNA pattern 
Table 3. Butanol-Producing bacterial identity

\begin{tabular}{clccl}
\hline No & \multicolumn{1}{c}{ Bacterial Species } & Source & Accession Number & \multicolumn{1}{c}{ References } \\
\hline 1 & Paenibacillus polymyxa RP 2.2 & East Java, Indonesia & KT036393 & This study \\
2 & Bacillus methylotrophicus RP 3.2 & East Java, Indonesia & KT036394 & This study \\
3 & Bacillus methylotrophicus RP 7.2 & East Java, Indonesia & KT036395 & This study \\
4 & Paenibacillus polymyxa CR1 & Ontario, Canada & KF620436 & Eastman et al., 2014 \\
5 & Bacillus amyloliquefaciens NELB-12 & Beijing, China & KF418240 & El-Hadi et al., 2014 \\
6 & Clostridium acetobutylicum ATCC 824 & Pennsylvania & U16166 & Bayer et al., 2008 \\
& & & & Al-Shorgani et al., 2011 \\
7 & Clostridium saccharoperbutylacetonicum N1-4 & Pennsylvania & U16122 & Bayer et al., 2008 \\
& & & & Al-Shorgani et al., 2011 \\
8 & Clostridium saccharobutylicum Ox29 & Freising, Germany & AM998793 & Bayer et al., 2008 \\
9 & Paenibacillus polymyxa WR-2 & Jiangsu, China & KF224925 & Eastman et al., 2014 \\
\hline
\end{tabular}

Table 4. Nucleic acid composition and butanol production of butanol-producing bacteria

\begin{tabular}{|c|c|c|c|c|c|c|c|}
\hline \multirow{2}{*}{ Bacterial Species } & \multicolumn{6}{|c|}{ Nucleic acid composition } & \multirow{2}{*}{$\begin{array}{c}\text { Butanol } \\
\text { production } \\
\left(\text { g. } L^{1}\right)\end{array}$} \\
\hline & $T$ & $C$ & $A$ & $G$ & $\% G+C$ & $\% A+T$ & \\
\hline Paenibacillus polymyха RP 2.2 & 19.8 & 23.5 & 25.5 & 31.2 & 54,70 & 45.30 & 10.34 \\
\hline Bacillus methylotrophicus RP 3.2 & 19.9 & 23.7 & 25.0 & 31.4 & 55.14 & 44.86 & 10.11 \\
\hline Bacillus methylotrophicus RP 7.2 & 19.8 & 23.9 & 24.9 & 31.5 & 55.33 & 44.67 & 9.63 \\
\hline Paenibacillus polymyха CR1 & 20.0 & 23.6 & 25.5 & 30.9 & 54.51 & 45.49 & NR \\
\hline Bacillus amyloliquefaciens NELB-12 & 19.9 & 23.7 & 24,9 & 31.5 & 55.25 & 44.75 & 8.9 \\
\hline Clostridium acetobutylicum ATCC 824 & 21.3 & 22.0 & 27.0 & 29.7 & 51.69 & 48.31 & 14.2 \\
\hline Clostridium saccharoperbutylacetonicum N1-4 & 21.5 & 21.6 & 26.5 & 30.4 & 52.01 & 47.99 & 0.47 \\
\hline Clostridium saccharobutylicum Ox29 & 21.6 & 21.4 & 27.0 & 29.9 & 51.35 & 48.65 & 9.2 \\
\hline Paenibacillus polymyxa WR-2 & 19.6 & 23.5 & 25.5 & 31,4 & 54.93 & 45.07 & $\mathrm{NR}^{*}$ \\
\hline
\end{tabular}

*NR: Number of reference

\section{$16 S$ rDNA profiling}

16S rDNA sequence composition were varied between all bacteria (Table 4). P. polymyxa RP 2.2 showed similarity in nucleotide composition (ATGC) with B. methylotrophicus RP 3.2, B. methylotrophicus RP 7.2, P. polymyxa CR1, B. amyloliquefaciens NELB12, and P. polymyxa WR-2. C. acetobutylicum ATCC 824 showed similarity in nucleotide composition (ATGC) with $C$. saccharoperbutylacetonicum N1-4, and C. saccharobutylicum $\mathrm{Ox} 29 . \mathrm{G}+\mathrm{C}$ content is about 51.35-55.35\%. The lowest $\mathrm{G}+\mathrm{C}$ content was $C$. saccharobutylicum Ox29 (51.35\%), and the highest was $B$. methylotrophicus RP 7.2 (55.33\%).

The environment plays an active role in shaping GC content, such as surface water vs. soil, and bacteria living in aquatic conditions have an average low GC content ( $\sim 34 \%)$, whereas soil-dwellers have an elevated high GC content ( 61\%) [17]. P. polymyxa RP 2.2, B. methylotrophicus RP 3.2, B. methylotrophicus RP 7.2 had $54-55 \% \mathrm{G}+\mathrm{C}$ content and isolated from sediment sample.

Sequences of $16 \mathrm{~S}$ rDNA were formed some patttterns, which are conserved region, variable region, Par simony informative site (PIS), single tone, 0 -fold degenerate site, 2-fold degenerate site and 4-fold degenerate site (Figure 1). Conserved region of $16 \mathrm{~S}$ rDNA (1044 bp) were consisted of 17 conserved sequences. The number of Parsimony Informative Site (PIS) was 319 spot and single tone was 48 spot. The number of 0 -fold degenerate site, 2 -fold degenerate site, and 4-fold degenerate site as much as 865,169 and 188 . There are 17 conserved sequences (Table 5). 
Table 5. Conserve region of butanol-producing bacterial sequences

\begin{tabular}{|c|c|c|c|}
\hline \multirow{2}{*}{ No. } & \multicolumn{2}{|c|}{ No. of base } & \multirow{2}{*}{ Nucleic Base (5'-3') } \\
\hline & Start & End & \\
\hline 1 & 45 & 69 & AGCGGCGGACGGGTGAGTAACACGT \\
\hline 2 & 235 & 261 & CGATGCGTAGCCGACCTGAGAGGGTGA \\
\hline 3 & 289 & 313 & CCAGACTCCTACGGGAGGCAGCAGT \\
\hline 4 & 348 & 369 & AGCAACGCCGCGTGAGTGATGA \\
\hline 5 & 467 & 503 & --CTAACTACGTGCCAGCAGCCGCGGTAATACGTAGG \\
\hline 6 & 505 & 521 & GGCAAGCGTTGTCCGGA \\
\hline 7 & 647 & 668 & GTGTAGCGGTGAAATGCGTAGA \\
\hline 8 & 682 & 697 & ACCAGTGGCGAAGGCG \\
\hline 9 & 729 & 743 & GAAAGCGTGGGGAGC \\
\hline 10 & 745 & 771 & AACAGGAT--TAGATACCCTGGTAGTC \\
\hline 11 & 773 & 789 & CACGCCGTAAACGATGA \\
\hline 12 & 859 & 874 & AGTACGGTCGCAAGA \\
\hline 13 & 937 & 966 & --AATTCGAAGCAACGCGAAGAACCTTACC \\
\hline \multirow[t]{2}{*}{14} & 1028 & 1100 & GACAGGTGGTGCATGGTTGTCGTCAGCTCGTGTCGTGAGATGTTGGGTTAAGT \\
\hline & & & CCCGCAACGAGCGCAACC \\
\hline 15 & 1165 & 1207 & GGAGGAAGGTGGGGATGA-CGTCAAATCATCATGCCCCTTATG \\
\hline 16 & 1366 & 1386 & CGCGGTGAATACGTTCCCGGG \\
\hline 17 & 1388 & 1412 & CTTGTACACACCGCCCGTCACACCA \\
\hline
\end{tabular}

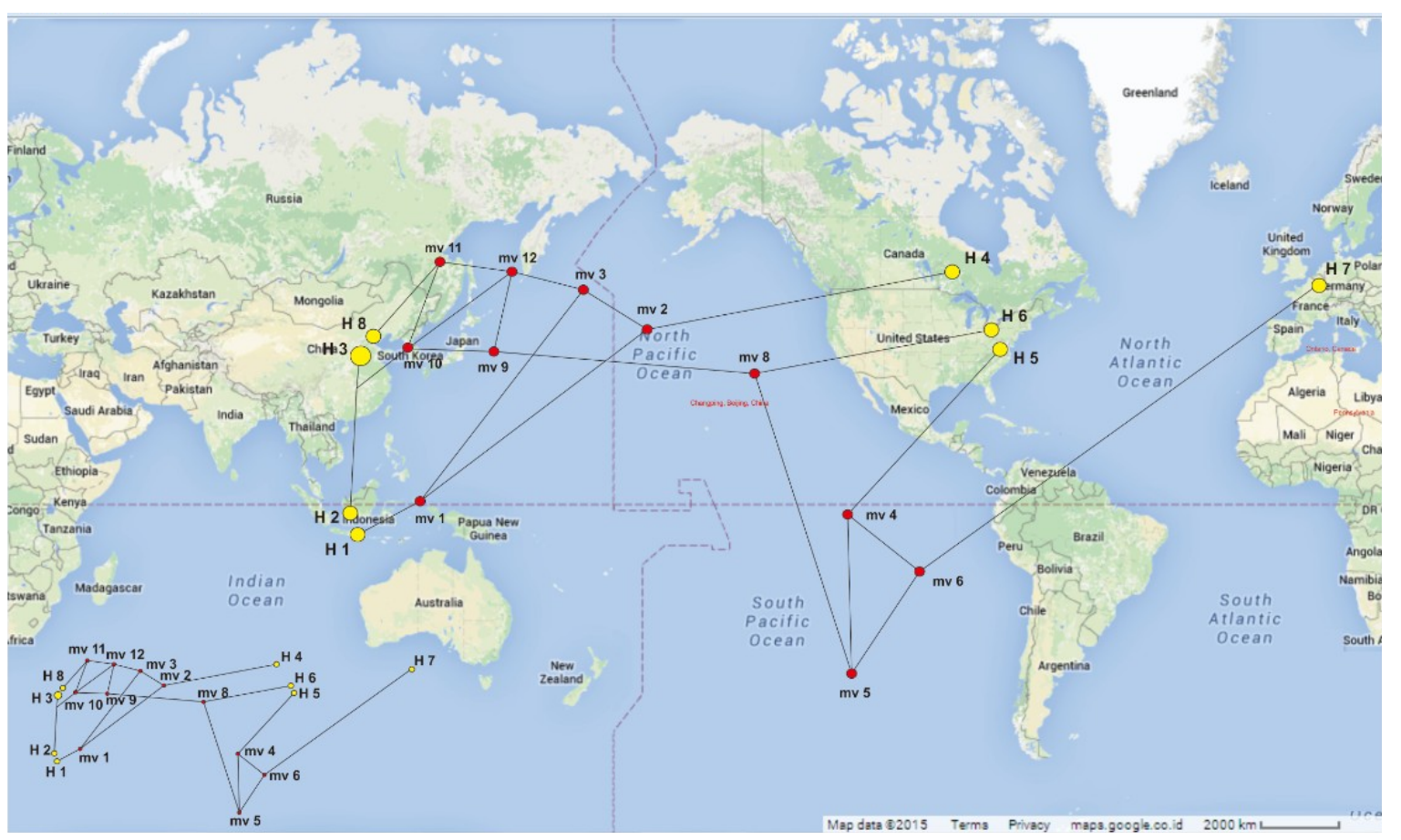

Figure 2. Haplotype network of butanol-producing bacteria (overlay with map) 
Table 6. Haplotype of butanol-producing bacterial sequences

\begin{tabular}{cl}
\hline Haplotype & \multicolumn{1}{c}{ Species of Bacteria } \\
\hline hap 1 & Paenibacillus polymyxa RP 2.2 \\
hap 2 & Bacillus methylotrophicus RP 3.2 \\
hap 3 & Bacillus methylotrophicus RP 7.2 \& Bacillus \\
& amyloliquefaciens NELB-12 \\
hap 4 & Paenibacillus polymyxa CR1 \\
hap 5 & Bacillus amyloliquefaciens NELB-12 \\
hap 6 & Clostridium acetobutylicum ATCC 824 \\
hap 7 & Clostridium saccharoperbutylacetonicum N1-4 \\
hap 8 & Paenibacillus polymyxa WR-2 \\
\hline
\end{tabular}

\section{Haplotype of $16 S$ rDNA}

All sequences of butanol-producing bacteria were grouped to 8 haplotypes (Figure 2). Haplotype 3 is consisting of $B$. amyloliquefaciens NELB-12 and $B$. methylotrophicus RP 7.2. Haplotype 1 is $P$. polymyxa RP 2.2, haplotype 2 is B. methylotrophicus RP 3.2. Another species were grouped to other haplotypes (Table 6). Based on the origin of sample, there were three haplotype groups. Group A was isolated from Asia (hap 1, 2, 3 and 8), group B was isolated from America (hap 4, 5 and 6) and group $C$ was isolated from Europe (Hap 7) (Figure 2). Bacteria from group A could produce butanol 8.9-10.34 g.L $\mathrm{L}^{-1}$, group B 9.2-14.2 g. $\mathrm{L}^{-1}$ and group C could produce butanol 0.47 g.L.' .

Distribution and difference of butanol-producing bacteria was caused by many factors. Bacteria are very influenced by environmental condition, such as temperature, altitude, humidity, gasses, salinity, biotic and other factors [18]. Distance of every ecosystems or micro-ecosystems gives significant of phenotype and genotype characteristics of bacteria [19].

Therefore, even under similar environmental conditions, microbial communities from different placeses might function differently. A better understanding of microbial biogeography is essential to predict such effffects. It is also crucial in the search for novel pharma ceutical and other compounds of industrial importance [7].

\section{CONCLUSIONS}

High butanol production were showed by $P$. polymyxa RP 2.2, B. methylotrophicus RP 3.2 and B. methylotrophicus RP 7.2 isolate. All isolates showed different nucleotid composition. All of butanol-producing bacterial DNA sequences have clustered to 8 haplotypes. The haplotype analysis of bacteria based on $16 \mathrm{~S}$ rDNA sequences in this study could predict capability of butanol production.

\section{ACKNOWLEDGMENT}

This research was supported and facilitated by PHK programs for graduate student of Biology Departement, University of Brawijaya, Malang, Indonesia.

\section{REFERENCES}

1. Pfromm PH, Boadu VA, Nelson R, Vadlani P, Madl R (2009) Bio-butanol vs. bioethanol: a technical and economic assessment for corn and switchgrass fermented by yeast or Clostridium acetobutylicum. Biomass Bioenergy 34: 515-524.

2. DÜrre P, (2008) Fermentative butanol production bulk chemical and biofuel. Annals of the New York Academy of Sciences 1125: 353-362.

3. Eastman WA, Weselowski B, Nathoo N, Yuan ZC (2014) Complete genome sequence of Paenibacillus polymyxa CR1, a plant growth-promoting bacterium isolated from the corn rhizosphere exhibiting potential for biocontrol, biomass degradation, and biofuel production. Genome Announcements 2(1): e01218-13.

4. El-Hadi D, Zheng Z, Dong C (2014) Aerobic production of butanol with Bacillus amyloliquefaciens NELB-12. Applied Mechanics and Materials 473: 1005-110.

5. Bayer EA, Lamed R, White BA, Flint HJ (2008) From cellulosomes to cellulosomics. The Chemical Record 8: 364377.

6. Ng CYC, Takahashi K, Liu Z (2015) Isolation, characterization, and optimization of an aerobic butanol producing bacterium from Singapore. Biotechnology and Applied Biochemistry 1343: 1-20.

7. Bull AT (ed). (2003) Microbial Diversity and Bioprospecting. ASM Press. Washington DC.

8. Ambarsari H, Sonomoto K (2013) Production of Acetone, Butanol, and as Bioenergy Source materials by Clostridium saccharoperbutylacetonicum N1-4 (ATCC 13564) using Different Substrates. Microbiology Indonesia 7 (3): 113-123.

9. Ausubel FM, Brent RE, Kingston DD, Moore JG, Seidman JA, Smith, Struht (1995) Short Protocol in Molecular Biology. Willey. New York.

10. Turner S, Pryer KM, Miao VPW, Palmer JD (1999) Investigating deep phylogenetic relationships among cyanobacteria and plastids by small subunit rRNA sequence analysis. Journal of Eukaryotic Microbiology 46: 327-338.

11. Liu FH, Wang SB, Zhang JS, Zhang J, Yan X, Zhou HK, Zhao GP, Zhou ZH (2009) The structure of the bacterial and archaeal community in a biogas digester as revealed by denaturing gradient gel electrophoresis and $16 \mathrm{~S}$ rDNA sequencing analysis. Journal of Applied Microbiology 106: 
952-966.

12. Al-Shorgani NKN, Kalil MS, Yusoff WMW (2011) The effffect of different carbon sources on biobutanol production using Clostridium saccharoperbutylacetonicum N1-4. Biotechnology 10 (3): 280-285.

13. Berezinaa OV, Brandtb A, Yarotskya S, Schwarzb WH, Zverlov VV (2009) Isolation of a new butanol-producing Clostridium strain: High level of hemicellulosic activity and structure of solventogenesis genes of a new Clostridium saccharobutylicum isolate. Systematic and Applied Microbiology 32: 449-459.

14. Lee J, Jang YS, Choi SJ, Im JA, Song H, Cho JH, Seung YD, Papoutsakis ET, Bennett GN, Lee SY (2012) Metabolic engineering of Clostridium acetobutylicum ATCC 824 for isopropanol-butanol-ethanol fermentation. Applied and Environmental Microbiology 78: 1416-1423.

15. Eastman WA, Heinrichs DE, Yuan ZC (2014) Comparative and genetic analysis of the four sequenced Paenibacillus polymyxa genomes reveals a diverse metabolism and conservation of genes relevant to plant-growth promotion and competitiveness. BMC Genomics 15 (851): 1471-2164.

16. Raza W, Yuan J, Ling N, Huang Q, Shen Q (2015) Production of volatile organic compounds by an antagonistic strain Paenibacillus polymyxa WR-2 in the presence of root exudates and organic fertilizer and their antifungal activity against Fusarium oxysporum f. sp. niveum. Biological Control 80: 89-95.

17. Foerstner KU, von Mering C, Hooper SD, Bork P (2005) Environments shape the nucleotide composition of genomes. EMBO Rep 6: 1208-1213.

18. Bassler B, Miller MB (2006) Quorum sensing. in M. Dworkin, S. Falkow, E. Rosenberg, K. H. Schleifer \& E. Stackebrandt. The Prokaryotes: ecophysiology and biochemistry, third edition. Springer science. Singapore.

19. Martiny JBH, Bohannan BJM, Brown JH, Colwell RK, Fuhrman JA, Green JL, Horner-Devine MC, Kane M, Krumins JA, Kuske CR, Morin PJ, Naeem S, Øvreås L, Reysenbach AL, Smith VH, Staley JT (2006) Microbial biogeography: putting microorganisms on the map. $\mathrm{Na}$ ture Reviews 4: 102-112. 